Journal of Management and Bussines (JOMB)

Volume 2, Nomor 1, Juni 2020

p-ISSN : 2656-8918

e-ISSN:2684-8317

DOI : https://doi.org/10.31539/jomb.v2i1.1218

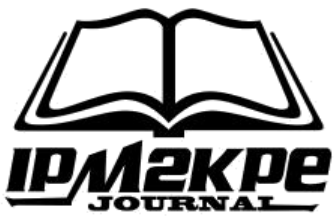

\title{
MENGUKUR KINERJA PERUSAHAAN DENGAN PENERAPAN METODE BALANCED SCORECARD PADA PT. PERKEBUNAN NUSANTARA VIII KEBUN SUKAMAJU CIBADAK KABUPATEN SUKABUMI
}

\author{
Hikmah Nurfaidah ${ }^{1}$, R.Deni Muhammad Daniel ${ }^{2}$, Faizal Mulia $Z^{3}$ \\ Universitas Muhammadiyah Sukabumi ${ }^{1,2,3}$ \\ hikmah.nurrahma@gmail.com ${ }^{1}$
}

\begin{abstract}
ABSTRAK
Tujuan penelitain ini adalah untuk mengetahui seberapa efektif dan efisien penerapan metode Balanced Scorecard terhadap kinerja perusahaan di PTPN. Metode yang digunakan dalam penelitian ini yaitu menggunkan metode Balanced Scorecard. Jenis penelitian deskriptif kuantitatif. Teknik pengumpulan data yang dilakukan peneliti dalam penelitian ini yaitu melalui observasi, wawancara, dokumentasi, dan studi kepustakaan. Hasil perhitungan dengan menggunakan rumus customer retention dengan persentase kemampuan perusahaan dalam mempertahankan pelanggan lama dapat dikatakan kurang baik. Simpulan, penerapan dengan metode balanced scorecard di PT. Perkebunan Nusantara VIII kebun Sukamaju, lebih komperhensif dan terukur, sehingga bagus dan perlu menerapkan pengukuran kinerja perusahaan dengan menggunakan metode balanced scorecard. Karena untuk memudahkan manajemen untuk mengontrol dan mengevaluasi kinerja perusahaan sehingga dapat bertahan dalam persaingan usaha dan merancang strategi perusahaan untuk jangka panjang.
\end{abstract}

Kata Kunci : Balanced Scorecard, Kinerja Perusahaan

\section{ABSTRACT}

The purpose of this research is to find out how effective and efficient the application of the Balanced Scorecard method to company performance at PTPN. The method used in this research is to use the Balanced Scorecard method. Type of quantitative descriptive research. Data collection techniques used by researchers in this research is through observation, interviews, documentation, and literature studies. The results of calculations using the customer retention formula with a percentage of the company's ability to retain old customers can be said to be less good. Conclusions, the application of the balanced scorecard method at PT. Perkebunan Nusantara VIII, Sukamaju plantation, is more comprehensive and measurable, so it is good and needs to implement company performance measurement using the balanced scorecard method. Because to make it easier for management to control and evaluate company performance so they can survive in business competition and design corporate strategies for the long term.

Keywords: Balanced Scorecard, Company Performance 


\section{PENDAHULUAN}

Perkembangan dan kemajuan global di era sekarang membuat perusahaan harus semakin giat berinovasi untuk bertahan dalam pangsa pasar, yang diharapkan dapat bersaing agar pendapatan perusahaan meningkat diiringi dengan semakin membaiknya sistem manajemen suatu perusahaan dan juga perencanaan strategi guna mewujudkan visi dan misi perusahaan di masa mendatang. Manajemen yang baik harus mempunyai stategi sehingga harus ada kreatifitas untuk mengembangkan manajemen agar memenuhi kebutuhan perkembangan lingkungan yang dinamis dengan mengutamakan future customers (apa keinginannya, apa harapannya, dan bagaimana persepsinya) (Kaplan, 2000).

Kendala yang akan di hadapinya adalah ketidak stabilan sebuah strategi yang umumnya disebabkan oleh ketidak tepatan dalam mengidentifikasi lingkungan bisnis perusahaan dan kegagalan dalam pengimplementasian strategi tersebut. Untuk menangani hal tersebut para manajemen harus bisa menyampaikan dengan baik berbentuk sebuah informasi, karena sistem informasi yang digunakan yaitu untuk mendukung pihak manajemen perusahaan dalam menerima, mengolah dan mengelola perusaahan secara baik dan sistematis dengan tujuan untuk mendukung penciptaan kinerja perusahaan yang baik. Sebuah organisasi profesional tidak akan mampu mewujudkan suatu kinerja manajemen yang baik tanpa ada dukungan yang kuat dari seluruh komponen manajemen perusahaan dan juga tentunya para pemegang saham (Kaplan, 1997).

Pengukuran kinerja perusaahaan yang masih menggunakan pendekatan kinerja tradisional di era perekonomian ini sudah tidak efektif karena hanya mengukur dari segi keuangan saja yang hanya mengejar profitability jangka pendek melalui analisis laporan keuangan, seperti: laporan laba rugi, Return On Asset (ROA), atau Return On Investment (ROI). Seperti yang di ketahui bahwa kondisi non keuangan ini sangat penting hal nya karena berkaitan dengan manjemen kinerja pada intern yang berpengaruh besar terhadap kemajuan perusahaan seperti : kepuasan pelanggan dan loyalitas pegawai dalam suatu proses bisnis. Adapun kelemahan dari pengukuran kinerja tradisional dalam segi keuangan adalah ketidak mampuan nya memberikan gambaran yang tidak luas dan lengkap mengenai kinerja perusahaan yang membuat suatu perusahaan tersebut kurang berkembang dalam segala aspek (Kaplan, 1992). 
Maka dari itu di terapkanlah suatu sistem atau metode pendekatan dengan mempertimbangkan 4 perspektif yaitu aspek keuangan, aspek pelanggan, aspek bisnis internal dan aspek pertembuhan dan pembelajaran. Metode ini dinamakan Balanced Scorecard merupakan sistem baru dalam manajemen yang menawarkan pengukuran kinerja guna membentuk kemampuan organisasi serta mengintregasikan visi. Dan juga dapat memungkinkan perusahaan untuk menilai investasi dalam pengembangan sumber daya manusia (SDM). Balanced scorecard terdiri dari dua kata yaitu pertama kartu score (scorecard) dan kedua berimbang (balanced), kartu score adalah kartu yang digunakan untuk mencatat score hasil kinerja suatu organisasi atau score individu. Kata berimbang dimaksudkan untuk menunjukan bahwa kinerja ogranisasi/individu diukur secara berimbang dari dua aspek: keuangan dan non keuangan, jangka pendek dan jangka panjang, internal dan eksternal (Mulyadi, 2001).

Dengan menerapkan metode balanced scorecard para manajer perusahaan akan mampu mengukur bagaimana unit bisnis mereka melakukan penciptaan nilai saat ini dengan tetap mempertimbangkan kepentingan-kepentingan masa yang akan datang. Balanced scorecard juga memberi manajemen organisasi suatu pengetahuan, keterampilan, dan sistem yang memungkinkan karyawan dan manajer belajar dan berkembang terus menerus dalam (aspek pembelajaran dan pertumbuhan) untuk selalu berinovasi untuk membangun kapabilitas yang strategis yang tepat serta efisien (aspek proses bisnis internal) agar mampu menyerahkan nilai spesifik kepasar (aspek pelanggan) dan selanjutnya akan mengarah pada nilai keuangan (aspek keuangan) yang akan terus menerus meningkat pertumbuhannya. Keunggulan dari metode ini yaitu menjadikan sistem manajemen kontemporer memiliki karakteristik yang tidak dimiliki oleh sistem manajemen tradisional yaitu karakteristik keterukuran dan keseimbangan dalam berpikir dan bertindak. Dari keunggulan tersebut diharapkan akan membentuk suatu manajemen kinerja yang bekerja secara efektif dan efisien. Karena pada prinsipnya penekanan efektif dan efisien merupakan kebahagiaan dari perintah dewan komisaris kepada pihak manajemen dalam memenuhi target terpenting adalah mampu menciptakan perolehan keuntungan (Mulyadi, 2001).

PT. Perkebunan Nusantara VIII Kebun Sukamaju Kabupaten Sukabumi ditemukan permasalahan kinerja perusahaan mengenai realisasi target produksi karet dengan berbagai faktor. Dari data yang didapat ternyata pada tiga bulan terakhir, 
ternyata hanya perspektif bisnis internal dan pertumbuhan dan pembelajaran yang mengalami peningkatan yang hampir mencapai target dari dana yang di realisasikan pada bulan September - November 2018.

\section{KAJIAN TEORI}

\section{Kinerja Perusahaan}

Kinerja perusahaan merupakan suatu gambaran tentang kondisi keuangan suatu perusahaan yang dianalisis dengan alat-alat analisis keuangan, sehingga dapat diketahui mengenai baik buruknya keadaan keuangan suatu perusahaan yang mencerminkan prestasi kerja dalam periode tertentu. Hal ini sangat penting agar sumber daya digunakan secara optimal dalam menghadapi perubahan lingkungan. Penilaian kinerja berupa aspek keuangan yang merupakan salah satu cara yang dapat di lakukan oleh para manajemen peusahaan agar dapat memenuhi kewajibannya terhadap para penyumbang dana dan juga untuk mencapai tujuan yang telah diterapkan perusahaan. Adapun pengertian tentang kinerja yaitu Performance adalah ukuran seberapa efektif dan efisien sebuah organisasi atau seorang manajer untuk mencapai tujuan yang memadai.

Adapun pengertian efisiensi menurut Susilo (2012) adalah suatu kondisi atau keadaan,dimana penyelesaian suatu pekerjaan dilaksanakan dengan benar dan dengan penuh kemampuan yang dimiliki.

\section{Pengkuran Kinerja}

Whittaker dalam Moeherino (2012) mendefinisikan pengukuran kinerja merupakan suatu alat manajemen yang digunakan untuk meningkatkan kualitas pengambilan keputusan dan akuntabilitas, serta untuk menilai pencapaian tujuan dan sasaran (goal sand objectives).

Pengukuran kinerja merupakan suatu tolok ukur atau bagi manajemen perusahaan dalam menentukan kebijakan perusahaan, apakah kinerja perusahaan sudah baik dari segi keuangan maupun non keuangan. 


\section{Penilaian Kinerja}

Mulyadi, Setyawan, (2001) mendefinisikan mengenai penilaian kinerja adalah "penentuan secara periodik efektivitas operasional organisasi, bagian organisasi, dan karyawannya berdasarkan sasaran, standar, dan kriteria yang telah ditetapkan sebelumnya. Melalui penilaian kinerja, manajer dapat menggunakannya dalam mengambil keputusan penting dalam rangka bisnis perusahaan, seperti menentukan tingkat gaji karyawan, dan sebagainya, serta langkah yang akan diambil untuk masa depan. Sedangkan bagi pihak luar, penilaian kinerja sebagai alat pendeteksi awal dalam memilih alternatif investasi yang digunakan untuk meramalkan kondisi perusahaan di masa yang akan datang."

\section{Balanced Scorecard}

merupakan suatu konsep yang bertujuan untuk mendukung perwujudan visi dan misi dan strategi perusahaan dengan target bersifat jangka panjang. Balanced scorecard terdiri dari dua kata (1) kartu skor (Scorecard) dan (2) berimbang (Balanced). Kartu skor adalah kartu yang digunkan untuk mencatat skor hasil kinerja suatu organisasi atau skor individu kata berimbang dimaksudkan untuk menunjukan bahwa kinerja organisasi/individu diukur seacra berimbang dari dua aspek: keuangan dan non keuangan, jangka pendek dan jangka panjang, internal dan eksternal. Konsep pengukuran kinerja dengan pendekatan balanced scorecard (Kaplan, David, 1992).

Kemudian seiring dengan perkembangan zaman permbahasan dan pengkajian balanced scorecard semakin berkembang, dan pembahasannya bukan hanya dilakukan didunia akademisi namun juga telah masuk ke sisi praktisi bisnis. Balanced Scorecard membahas tentang penggunaan dalam mendukung penguatan manajemen kinerja di suatu organisasi. Balanced Scorecard digunakan untuk menciptakan suatu gabungan pengukuran strategis, pengukuran finansial dan non finansial serta pengkuran ekstrn dan intern pengukuran perusahaan dan dipandang menjadi empat kategori perspektif, yaitu: perspektif finansial, perspektif langganan, perspektif internal bisnis, serta perspektif pembelajaran dan pertumbuhan. Ke-empat perspektif ini saling berhubungan dalam sebab akibat, sebagai cara untuk menerjemahkan stategi ke dalam tindakan.

Empat aspek yang diukur, yaitu: perspektif keuangan, perspektif pelanggan, perspektif proses binsin internal, serta perspektif pembelajaran dan pertumbuhan. 


\section{Perspektif Keuangan}

Pengukuran kinerja keuangan akan menunjukan apakah perencanaan strategi memberikan perbaikan yang mendasar bagi keuntungan perusahaan. Kaplan dan Norton (2000) mengungkapkan bahwa pengukuran kinerja perusahaan bila ditinjau dari perspektif keuangan pada rasio profitabilitas ada tiga yang sering dibicarakan, yaitu Profit Margin, dan Return On investment (ROI).

\section{ROI Return on Investment ( Rasio pengembalian dan Investasi)}

$$
\text { ROI }=\frac{\text { EAT }}{\text { Total aktiva }} \quad X 100=\ldots . . \%
$$

Profit margin

$$
\text { Profit margin }=\frac{\text { EAT }}{\text { Penjualan }} \quad x 100=\ldots \ldots \%
$$

\section{Perspektif Pelanggan}

Perspektif ini merupakan leading indicator. Jadi, jika pelanggan tidak puas, meraka akan mencari produsen lain yang sesuai dengan kebutuhan meraka. Pada perspektif ini perusahaan mengidentifikasikan dan mendefinisikan pelanggan dan segmen pasarnya.

\section{Tingkat Perolehan Pelanggan Baru (Customer Acquistion)}

Costomer acquistion = jumalah pelanggan baru

$$
\frac{\text { Jumlah total pelanggan }}{X 100}=\ldots . . . \%
$$

\section{Kemampuan Mempertahankan Pelanggan Lama (Customer Retention)}

$$
\text { Customer retention }=\frac{\text { jumlah pelanggan lama }}{\text { Jumlah total pelanggan }} \quad X 100=\ldots \ldots \%
$$

\section{Tingkat Kepuasan Pelanggan (Customer Satisfaction) Mengukur Tingkat}

Kepuasan para pelanggan terhadap layanan perusahaan

\section{Perspektif Bisnis Internal}

Merupakan proses internal yang harus dilakukan adalah proses yang berhubungan dengan penciptaan barang dan jasa sehingga dapat menarik dan 
mempertahankan pelanggan di pasar yang akhimya dapat memuaskan ekspektasi pemegang saham.

\section{Proses inovasi}

$$
\text { Inovasi }=\frac{\text { produk baru yg ditawarkan }}{\text { Total produk yg sudah ada }} \quad X 100=\ldots \ldots \%
$$

\section{Proses Operasi}

Proses operasi adalah proses untuk membuat dan menyampaikan produk/jasa.

\section{Perspektif Pertumbuhan dan Pembelajaran}

Perspektif ini mengindentifikasi infrastruktur yang harus dibangun perusahaan untuk membentuk pertumbuhan dan perkembangan perusahaan di jangka panjang.

Kepuasan karyawan merupakan prakondisi untuk meningkatkan produktivitas, tanggungjawab, kualitas, dan pelayanan kepada konsumen.

Produktivitas, untuk mengetahui produktivitas karyawan dalam periode tertentu. Produktivitas pekerja merupakan hasil dari pengaruh keseluruhan dari peningkatan keahlian dan moral, inovasi, proses internal, dan kepuasan pelanggan.

Produktivitas $=$ laba bersih

Jumlah karyawan

\section{METODE PENELITIAN}

Dalam penelitian ini peneliti menggunakan metode pendekatan penelitian Desriptif dan Kuantitatif. Berdasarkan pendapat para ahli diatas dapat disimpulkan bahwa penelitian deskriptif dengan pendekatan kuantitatif adalah digunakan untuk mendeskripsikan suatu kejadian atau peristiwa dalam bentuk angka yang bermakna. Skema untuk mengukur kinerja perusahaan dengan metode balanced scorecard.

\section{HASIL PENELITIAN}

Berdasarkan analisis tentang pentingnya peran metode balanced scorecard untuk mengukur kinerja perusahaan, maka peneliti menerapkan metode tersebut untuk menilai kinerja PT. Perkebunan Nusantara VIII kebun Sukamaju Cibadak Kab. Sukabumi. Metode balanced scorecard mempunyai empat perspektif, yaitu perspektif 
keuangan, pelanggan, proses bisnis intenal dan pertumbuhan dan pembelajaran, maka dari itu peneliti akan menguraikan sebagai berikut:

\section{Perspektif Keuangan \\ ROI (Return on Investment)}

Tabel 1 ROI (Return On Investment)

PT. Perkebunan Nusantara VIII kebun sukamaju Cibadak Kab.Sukabumi

\begin{tabular}{cccc}
\hline Bulan & September & Oktober & November \\
\hline EAT (Laba & Rp. 1.518.184.000 & Rp. 1.425.717.000 & Rp. 1.797.877.000 \\
setelah pajak) & & & \\
Total Aktiva & Rp. 2.678.295.965 & Rp. 3.709.620.746 & Rp. 2.946.860.758 \\
\hline ROI & $57,69 \%$ & $37,83 \%$ & $58,62 \%$ \\
\hline
\end{tabular}

Sumber : PT.Perkebunan Nusantara VIII.2018

Dari tabel 1 diatas dapat di simpulkan bahwa ROI (Return On Investment) PT. Perkebunan Nusantara VIII kebun sukamaju mengalami peningkatan pada bulan september ROI 57,69\%, pada bulan oktober mengalami peningkatan yang cukup besar ROI menjadi 37,83\% dan yang terakhir pada bulan november mengalami penurunan ROI menjadi 58,62\%. Penurunan tersebut disebabkan karena hasil penjualan produk yang didapat perusahaan menaglami penurunan yang berdampak pada EAT (laba setelah pajak) dan dalam menggunakan rumus ROI pun mengalami penurunan persentase. Maka dari itu melakukan perhitungan ROI, perusahaan dapat melihat modal yang diinvestasikan dalam keseluruhan aktiva yang menghasilkan laba bersih dalam perusahaan. Untuk itu, dapat disimpulkan kemampuan modal yang diinvestasikan dalam PT.Perkebunan Nusantara VIII kebun Sukamaju belum dapat dikatakan baik atau sehat. Karena masih mengalami penurunan yang terdapat pada ROI.

\section{Profit Margin}

Tabel 2 Penjualan PT. Perkebunan Nusantara VIII

Kebun Sukamaju Cibadak Kab.Sukabumi

\begin{tabular}{cccc}
\hline Bulan & September & Oktober & November \\
\hline $\begin{array}{c}\text { EAT ( Laba } \\
\text { setelah pajak) }\end{array}$ & Rp. 1.518.184.000 & Rp. 1.425.717.000 & Rp. 1.797.877.000 \\
\hline Penjualan & Rp. 1.304.575.000 & Rp. 1.602.005.000 & Rp. 1.753.205.000 \\
\hline Profit Margin & $115 \%$ & $87,5 \%$ & $100 \%$ \\
\hline Sumber : PT.Perkebunan Nusantara VIII.2018 & &
\end{tabular}


Dari tabel 2 menunjukan bahwa laba usaha yang berhubungan dengan penjualan menglami penurunan dilihat dari rata-rata profit margin pada PT. Perkebunan Nusantara VIII kebun Sukamaju pada bulan oktober sebesar $87,5 \%$ penurunan yang cukup besar dari bulan sebelumnya. Dan pada bulan november naik menjadi 100\%. Tujuan dihitungnya profit margin untuk mengetahui nilai laba usaha yang berhubungan dengan penjualan diperusahaan. Penurunan penjulan pada bulan oktober disebabkan oleh pengiriman produk atau barang kepada konsumen yang mengalami keterlambatan. Keterlambatan terjadi karena alat transportasi yang kurang perawatan. Maka dari itu, berdampak pula pada penjualan dan pada laba yang dihasilkan oleh perusahaan PT. Perkebunan Nusantara VIII kebun sukamaju dalam profit margin masih kurang baik.

\section{Perspektif Pelanggan}

\section{Tingkat Perolehan Pelanggan Baru (Customer Acquision)}

Tabel 3 Tingkat perolehan pelanggan baru PT. Perkebunan Nusantara VIII Kebun Sukamaju Cibadak Kab.Sukabumi

\begin{tabular}{cccc}
\hline Bulan & September & Oktober & November \\
\hline $\begin{array}{c}\text { Jumlah pelanggan baru } \\
\text { (Perusahaan) }\end{array}$ & 6 & 8 & 9 \\
\hline $\begin{array}{c}\text { Jumlah total pelanggan } \\
\text { (Perusahaan) }\end{array}$ & 22 & 22 & 22 \\
\hline Customer acquision & $27,27 \%$ & $36,36 \%$ & $40,09 \%$ \\
\hline
\end{tabular}

Sumber : PT.Perkebunan Nusantara VIII.2018

Dari tabel 3 dapat dilihat bahwa jumlah pelanggan baru pada PT. Perkebunan Nusantara VIII kebun Sukamaju mengalami kenaikan dari bulan ke bulan. Ini disebabkan karena pelanggan mearasa puas dengan pelayanan dan produk yang diberikan pada pelanggan. Dihitung dengan rumus customer acquisition di PT.Perkebunan Nusantara kebun Sukamaju mengalami nilai persentase, bulan september tingkat perolehan pelanggan baru $27,27 \%$, pada bulan oktober meningkat menjadi 36,36\% dan pada bulan november menjadi 40,09\%. Tujuan dihitungnya tingkat perolehan pelanggan baru untuk mengavaluasi dan mengetahui berapa persentase yang dihasilkan setiap bulannya dari perusahaan dalam memperoleh pelanggan baru. Dapat disimpulkan pada PT.Perkebunan Nusantara VIII dalam memperoleh pelanggan baru dinilai cukup baik, karena perusahaan mampu menarik pelanggan baru setiap bulan nya dengan cara inovasi dan keatifitas yang dilakukannya. 


\section{Kemampuan Mempertahankan Pelanggan Lama (Customer Retention)}

Tabel 4 Tingkat mempertahankan pelanggan lama

PT. Perkebunan Nusantara VIII kebun Sukamaju Cibadak Kab.Sukabumi

\begin{tabular}{cccc}
\hline Bulan & September & Oktober & November \\
\hline $\begin{array}{c}\text { Jumlah pelanggan lama } \\
\text { (Perusahaan) }\end{array}$ & 16 & 14 & 13 \\
\hline $\begin{array}{c}\text { Jumlah total pelanggan } \\
\text { (Perusahaan) }\end{array}$ & 22 & 22 & 22 \\
\hline Customer retention & $72,72 \%$ & $63,63 \%$ & $59,09 \%$ \\
\hline
\end{tabular}

Sumber : PT.Perkebunan Nusantara VIII.2018

Dari tabel 4 bahwa jumlah pelanggan lama mengalami penurunan dari bulan ke bulan berbanding dengan pelanggan baru. Hal ini disebabkan pelanggan kurang puas dengan pengiriman barang yang membutuhkan waktu cukup lama. Hasil perhitungan dengan menggunakan rumus customer retention dengan persentase kemampuan perusahaan dalam mempertahankan pelanggan lama dapat dikatakan kurang baik. Karena hasil persentase dari bulan ke bulan menunjukan penurunan yang cukup signifikan mulai dari bulan september yaitu $72,72 \%$, pada bulan oktober menjadi 63,63\% dan pada bulan november 59,09\%. Dari hail tersebut dapat disimpulkan kemampuan mempertahankan pelanggan lama pada PT. Perkbunan Nusantara VIII dapat dikatakan kurang baik. Tujuan dihitungnya customer retention utnuk mengetahui seberapa besar persentase yang dihasilkan perusahaan dalam mempertahankan pelanggan lama. Perusahaan diharapkan dapat mempertahankan pelanggan lama dengan mengevaluasi dari permaslahan yang terjadi pada unit kendaraan pengiriman yang mungkin harus di upgrade.

\section{Tingkat Kepuasan Pelanggan}

\section{Perspektif Proses Bisnis Internal}

\section{Proses inovasi}

Tabel 5 Inovasi Produk PT. Perkebunan Nusantara VIII

Kebun Sukamaju Cibadak Kab.Sukabumi

\begin{tabular}{cccc}
\hline Bulan & September & Oktober & November \\
\hline $\begin{array}{c}\text { Produk yang ditawarkan } \\
\text { (Produk) }\end{array}$ & 3 & 4 & 5 \\
\hline $\begin{array}{c}\text { Produk yang sudah ada } \\
\text { (Produk) }\end{array}$ & 6 & 6 & 6 \\
\hline Inovasi & $50 \%$ & $66 \%$ & $83 \% \%$ \\
\hline
\end{tabular}

Sumber : PT.Perkebunan Nusantara VIII.2018 
Berdasarkan tabel 5 dapat dilihat proses inovasi produk pada PT. Perkebunan Nusantara VIII meningkat pada bulan september menjadi 50\% hasil dari 3 produk yang ditawarkan yaitu : Ribbed Smoked Sheets 1, Ribbed Smoked Sheets 2, Ribbed Smoked Sheets 3. Bulan oktober meningkat menjadi $66 \%$ hasil dari 4 produk yang ditawarkan yaitu : Karet Cair (Latek), Ribbed Smoked Sheets 3, SIR 3L dan Cut A hasil potongan RSS. Dan bulan november meningkat kembali menjadi $83 \%$ hasil dari 5 produk yang ditawarkan yaitu : Karet cair (latek), RSS 1, RSS 2, SIR 3L, Cut A hasil potongan RSS, dari 6 produk yang sudah ada. Peningkatan ini disebabkan perusahaan menawarkan lebih dari satu produk, produk yang ditawarkan berupa produk sejenis yakni berupa produk berbahan dasar karet cair (latek) yang diterima dari petani pengumpul, tetapi yang membedakannya dari produk tersebut adalah kualitas produk.

\section{Proses Operasi}

Proses operasi pada PT.Perkebunan Nusantara VIII kebun Sukamaju dapat dilihat dari proses pembuatan produk dari hasil study lapangan dengan pihak PT. Perkebunan Nusantara VIII kebun Sukamaju waktu produk membutuhkan waktu seminggu dengan proses rincian sebagai berikut :

\section{Persfektif Pertumbuhan dan Pembelajaran}

\section{Kepuasan Karyawan}

Kepuasan karyawan merupakan kondisi dimana karyawan harus meningkatkan produktivitas, tanggung jawab, kualitas dan pelayanan kepada konsumen. Unsur-unsur kepuasan karyawan yang dapat diukur meliputi ketertiban perkerja dalam mengambil sebuah keputusan, pengakuan, akses untuk mendaptkan informasi, dorongan untuk bekerja kreatif dan inovatif, dan menggunakan inisiatif, serta dukungan dari atasan.

\section{Retensi Karyawan}

Retensi karyawan merupakan upaya perusahaan yang dilakukan untuk mempertahankan pekerja terbaik yang dimilikinya. Karena pekerja menrupakan aset terpenting bagi perushaan jangka panjang, retensi karyawan juga merupakan solusi terbaik untuk meminimalisir turnover karywannya serta meningkatkan rasa nyaman karyawan dalam sebuah perusahaan. Pada PT.Perkebunan Nusantara VIII kebun 
Sukamaju retensi karyawan dikatakan baik dari sisi pelajaran maupun sisi pelatihan karyawan. PT. Perkebunan Nusantara VIII kebun Sukamaju jga memberikan seminar umum untuk semua karyawan yang berada di perusahaan setiap setahun 1 kali diadakannya pelatihan dan pembelajaran seminar khusus untuk semua karyawan, baik diadakannya di dalam perusahaan maupun luar perusahaan.

\section{Produktivitas}

Produktivitas untuk mengetahui produktivitas karyawan dalam periode tertentu. Produktivitas pekerja merupakan hasil dari pengaruh keseluruhan dari peningkatan keahlian dan moral, inovasi, proses internal, dan kepuasan pelanggan. Tujuannya adalah untuk menghubungkan output yang dihasilkan oleh pekerja dengan jumlah pekerja yang seharusnya untuk menghasilkan output tersebut.

Tabel 6 Tingkat perolehan pelanggan baru PT. Perkebunan Nusantara VIII Kebun Sukamaju Cibadak Kab.Sukabumi

\begin{tabular}{|c|c|c|c|}
\hline Bulan & September & Oktober & November \\
\hline Laba bersih & Rp. 1.518.184.000 & Rp. 1.425.717.000 & Rp. 1.797.877.000 \\
\hline Jumlah karyawan & 701 & 689 & 689 \\
\hline Produktivitas & Rp. 2.165 .740 & Rp. 2.069.255 & Rp. 2.609 .4000 \\
\hline
\end{tabular}

Sumber : PT.Perkebunan Nusantara VIII.2018

Dari tabel 6 dapat di lihat produktivitas karyawan dihitung dalam bentuk rupiah. Produktivitas yang dimaksud adalah hasil dari laba bersih dibagi jumlah karyawan yang hasilnya untuk perusahaan. Pada PT. Perkebunan Nusantara VIII kebun sukamaju mengalami penurunan tetapi tidak terlalu signifikan karena di bulan selanjutnya mengalami penaikan yang dapat menutup kerugian di bulan sebelumnya.

\section{PEMBAHASAN}

\section{Tingkat Kepuasan Pelanggan}

\section{Perspektif Proses Bisnis Internal}

\section{Proses inovasi}

Berdasarkan tabel 5 dapat dilihat proses inovasi produk pada PT. Perkebunan Nusantara VIII meningkat pada bulan september menjadi 50\% hasil dari 3 produk yang ditawarkan yaitu : Ribbed Smoked Sheets 1, Ribbed Smoked Sheets 2, Ribbed Smoked Sheets 3. Bulan oktober meningkat menjadi $66 \%$ hasil dari 4 produk yang ditawarkan yaitu : Karet Cair (Latek), Ribbed Smoked Sheets 3, SIR 3L dan Cut A hasil potongan 
RSS. Dan bulan november meningkat kembali menjadi $83 \%$ hasil dari 5 produk yang ditawarkan yaitu : Karet cair (latek), RSS 1, RSS 2, SIR 3L, Cut A hasil potongan RSS, dari 6 produk yang sudah ada. Peningkatan ini disebabkan perusahaan menawarkan lebih dari satu produk, produk yang ditawarkan berupa produk sejenis yakni berupa produk berbahan dasar karet cair (latek) yang diterima dari petani pengumpul, tetapi yang membedakannya dari produk tersebut adalah kualitas produk. Produk yang ditawarkan PT. Perkebunan Nusantara VIII yaitu : Karet Cair (latek), Ribbet Smoked Sheets RSS 1, Ribbet Smoked Sheets RSS 2, Ribbet Smoked Sheets RSS 3 serta produk yang lain, SIR 3L (Standar Indonesia Rubber) dan Cut A hasil potongan RSS.

Tujuan untuk inovasi produk bagi perusahaan untuk memperbanyak produk yang ditawarkan ke customer serta dapat meningkatkan hasil penjualan dan laba pada PT. Perkebunan VIII dan meningkatkan kinerja perusahaan. PT. Perkebunan Nusantara VIII seharusnya memperbanyak inovasi produk dan menambah kapasital teknologi dalam pembuatan produk, dapat juga produk ditambah dengan adanya mesin menghasilkan produk ban mobil yang berdasarkan bahan karet. Agar dapat menambah hasil penjualan dan laba perusahaan.

\section{Proses Operasi}

Proses operasi pada PT.Perkebunan Nusantara VIII kebun Sukamaju dapat dilihat dari proses pembuatan produk dari hasil study lapangan dengan pihak PT. Perkebunan Nusantara VIII kebun Sukamaju waktu produk membutuhkan waktu seminggu dengan proses rincian sebagai berikut :

Hari pertama bahan baku yang berupa latek (karet yang berbentuk cair) yang sudah dikumpulkan dari petani pengumpul latek, latek akan dicuci dimesin pencucian. Dan dilanjutkan percetakan atau penggilingan produk yang kan dilakukan pada malam hari, hasil dari percetakan/penggilingan menghasilkan bentuk seperti kulit hewan.

Hari kedua, produk yang setangah jadi di bawa ke niang pengasapan selama sehari. Hari ketiga, masih dilakukannya pengasapan. Dan hari ke empat, ke lima dan ke enam masih dilakukannya pengasapan pada produk.

Hari ke tujuh, produk yang sudah di asapkan akan dibawa pada bagian pengolahan yang akan di gunting atau dipilih produk yang masih mentah atau cacat 
dipisahkan akan dilakukannya pengasapan ulang serta di ruang pengolahan produk juga akan di timbang dan di kepak yang akan di kirim ke customer.

\section{Persfektif Pertumbuhan dan Pembelajaran}

\section{Kepuasan Karyawan}

Kepuasan karyawan merupakan kondisi dimana karyawan harus meningkatkan produktivitas, tanggung jawab, kualitas dan pelayanan kepada konsumen. Unsur-unsur kepuasan karyawan yang dapat diukur meliputi ketertiban perkerja dalam mengambil sebuah keputusan, pengakuan, akses untuk mendaptkan informasi, dorongan untuk bekerja kreatif dan inovatif, dan menggunakan inisiatif, serta dukungan dari atasan. Penilain kepuasan karyawan di PT. Perkebunan Nusantara VIII kebun Sukamaju dapat disimpulkan cukup baik karena dilihat dari absensi karyawan menjadi lebih csnggih dan simple, semua dilakukan secara disiplin, absensi terisi lengkap dan tidak ada karyawan yang absen dan terlambat masuk kerja.

\section{Retensi Karyawan}

Retensi karyawan merupakan upaya perusahaan yang dilakukan untuk mempertahankan pekerja terbaik yang dimilikinya. Karena pekerja menrupakan aset terpenting bagi perushaan jangka panjang, retensi karyawan juga merupakan solusi terbaik untuk meminimalisir turnover karywannya serta meningkatkan rasa nyaman karyawan dalam sebuah perusahaan. Pada PT.Perkebunan Nusantara VIII kebun Sukamaju retensi karyawan dikatakan baik dari sisi pelajaran maupun sisi pelatihan karyawan. PT. Perkebunan Nusantara VIII kebun Sukamaju jga memberikan seminar umum untuk semua karyawan yang berada di perusahaan setiap setahun 1 kali diadakannya pelatihan dan pembelajaran seminar khusus untuk semua karyawan, baik diadakannya di dalam perusahaan maupun luar perusahaan.

Dapat disimpulkan bahwa PT. Perkebunan Nusantara VIII kebun Sukamaju sudah menerapkan pelatihan dan pembelajaran bagi karyawan tetepi masih ada kekurangan yaitu waktu pelatihan dan pembelajaran lama diadakan atau diselenggarkan pelatihan dan pembelajaran karyawan. Disebabkan perusahaan memfokuskan pada proses produksi dan menghasilkan laba yang berdampak kurangnya pemerhatian pada karyawan dalam pembelajaran dan pelatihan. Diharapkan perusahaan pada PT. 
Perkebunan Nusabtara VIII kebun Sukamaju lebih meningkatkan waktu pelatihan dan pembelajaran karyawan.

\section{SIMPULAN}

Berdasarkan pembahasan yang dilakukan oleh peneliti pada penelitian ini, maka peneliti menyimpulkan pengukuran kinerja PT. Perkebunan Nusantara VIII kebun Sukamaju Cibadak kab.Sukabumi dengan penerapan metode balamced scorecard sebagai berikut :

1. Pengukuran kinerja PT. Perkebunan Nusantara VIII kebun sukamaju yang dilihat dari perspektif keuangan.

Adapun sasaran strategis pada perspektif keuangan adalah effective investment, cost efficiency, dan sustainable profit growth. Indikator yang digunakan untuk mengukur kinerja sasaran strategis keunagan adalah ROI (Return on investment), dan profit margin. Untuk penerapan metode balanced scorecard cukup baik walaupun mengalami penurunan di bulan oktober yang di sebabkan oleh beberpa faktor tetapi yang menonjol adalah faktor dari perspektif non finansial yang berpengaruh pada laba bersih.

2. Pengukuran kinerja PT. Perkebunan Nusantara VIII kebun sukamaju yang dilihat dari perspektif pelanggan.

Adapun sasaran strategis pada perspektif pelanggan adalah product quality, corporate image, customer satisfaction. Indikator yang digunakan untuk mengukur kinerja sasaran strategis tersebut adalah : customer acqusition dan customer retention. Untuk penerapan metode balanced scorecard baik dalam memikat pelanggan baru pada setiap bulannya tetapi yang disayangkan dalam mempertahankan pelanggan lama menurun setiap bulannya, karena proses pengiriman yang memakan waktu disebabkan unit kendaraan pengiriman yang harus di upgrade.

3. Pengukuran kinerja PT. Perkebunan Nusantara VIII kebun sukamaju yang dilihat dari perspektif bisnis internal

Adapun sasaran strategis pada perspektif bisnis internal adalah high supply performance, compliace with regulatory \& standard operational excellent. Indikator yang digunakan untuk mengukur kinerja sasaran strategis tersebut adalah proses 
inovasi dan proses operasi. Dalam penerapan metode balanced scorecard sangat baik karena proses inovasi yang mengalami peningkatan setiap bulannya yang sangat signifikan, karena perusahaan menawarkan lebih dari satu produk dan berpariasi.

4. Pengukuran kinerja PT. Perkebunan Nusantara VIII kebun sukamaju yang dilihat dari perspektif pertumbuhan dan pembelajaran.

Adapun sasaran strategis pada perspektif pertumbuhan dan pembelajaran adalah well trained employee, employee satisfaction, employee productiity, information tecnology performance. Indikator yang digunakan yang digunakan untuk mengukur kinerja sasaran strategis tersebut adalah kepuasan karyawan, retensi karyawan dan produktivitas. Dalam penerapan metode balanced scorecard baik karena dari semua indikator di jalankan sesuai SOP perusahaan dan produktivitas perusahaan selalu meningkat setiap bulannya.

5. Model pengukuran menggunakan metode balanced scorecard yang digunakan dalam pengukuran kinerja dapat digunakan oleh PT. Perkebunan Nusantara VIII kebun sukamaju dalam rangka memudahkan manajemen untuk mengontrol dan mengevaluasi kinerja perusahaan sehingga dapat bertahan dalam persaingan usaha dan merancang strategi perusahaan untuk jangka panjang.

\section{DAFTAR PUSTAKA}

Kaplan, R. S., \& David, P, N. (1992). The Balanced Scorecard-Meansure that Drive Performance, Harvard Business Riview : 71-79

Kaplan, R. S., \& David, P, N. (1996). Translating Strategy Into Action The Balanced Scorecard. Harvard Bussiness School. Boston

Kaplan, R. S., \& David, P, N. (2000). The Balanced Scorecard: Menetapkan Stretegi Menjadi Aksi. Boston, MA : Harvard Business School Press

Moeherino, M. (2012). Pengukuran Kinerja Berbasis Kompetensi. Edisi Revisi-Cetakan Pertama. Jakarta: Rajawali

Mulyadi, M. (2001). Balanced Scorecard Alat Kontemporer untuk Pelipatganda Kinerja Keuangan Perusahaan. Jakarta: Salemba Empat

Mulyadi, M., \& Setiawan, J. (2001). Sistem Perencanaan dan Pengendalian Manajemen. Jakarta: Salemba Empat

Susilo, E. (2012). Efisiensi Pendayagunaan Tempat Tidur dengan Metode Grafik Barber Johnson di RS Lancang Kuning. Jurnal Kesehatan Komunitas, 1(4), 181-187. https://doi.org/10.25311/keskom.Vol1.Iss4.24 